\title{
The role of milk in Swedish pre-school children's diet
}

\author{
By Hanna Sepp, Yngve Hofvander and Lillemor Abrahamsson \\ Received: February 19, 2001; Revised: August 15, September 27, 2001; Accepted: October 1, 2001
}

\begin{abstract}
Objective: A pre-school-based dietary survey, was carried out in Sweden in the Stockholm area. The aim was to study the role of milk in pre-school children's diet, especially the effect of milk versus water as lunch beverage at pre-school.

Design: Food and nutrient intake were quantified using seven day-records in order to compare two serving systems at pre-schools, one offering milk as lunch beverage, the other water and to analyse the quality of the diet of low and high consumers of milk.

Results: No significant differences between the children's food, nutrient or energy intake were attributable to the serving system at the pre-school. The low milk consumers had a more even distribution of energy intake from different food groups than did the high milk consumers.

Conclusions: This comparative study has provided no evidence to support the selection of water versus milk as a preferable lunch beverage in terms of pre-school children's total milk consumption and general dietary quality. The dietary analyses showed that there might be a reason to limit pre-school children's daily milk and fermented milk intake to half a litre if the refined sugar level is limited.
\end{abstract}

Key words: Children, energy, milk, nutrient, pre-school, water

\section{Introduction}

The Swedish National Food Administration (NFA) has developed dietary guidelines for pre-schools including recommendations for daily nutritional intake and meal composition (1). In this connection, children's milk intake has been of special interest, both the amount and the distribution over different meals. Since 1973 there has been a recommendation to limit preschool children's daily intake of milk to half a litre (including fermented milk), since that amount would cover $75 \%$ of the calcium and protein intakes (2-5). There seem to be no dietary studies verifying the theoretical based assuption that half a litre is sufficient. NFA recommends that milk and milk products be served at breakfast and at snack meals. Consequently, it is recommended that water be served at lunch and dinner although milk has traditionally been served in most homes and at school lunch.

The NFA guideline, to serve water as a meal drink instead of milk, has been debated. The argument has focused on three themes: milk as energy source, milk and iron content and absorption, and milk versus soft drinks. Milk may be considered as a competitor to other foods, and if milk intake is high there is a risk that especially iron and fibre intake will be low and protein intake too high (1,3-5). Scientific opinion about the association between iron status and milk consumption is divided: one side argues that milk consumption in a single meal has an effect on iron absorption (6-11); the other side argues that there are no such long-term effects since the body has mechanisms that regulate absorption and that can, within certain limits, fill the iron stores when needed (12-16). The consumption of soft drinks and juices is increasing in Western society, and that of milk is decreasing, resulting in less nutrient-rich beverages replacing the nutrientrich milk (17-22).

One aim of the present study was to compare the respective effects of two pre-school serving systems in terms of children's

\footnotetext{
Hanna Sepp ${ }^{1}$, MSc, Yngve Hofvander ${ }^{2}$, Prof., Lillemor Abrahamsson ${ }^{1}, \mathrm{PhD}$

${ }^{1}$ Dept of Domestic Sciences, Uppsala University, Uppsala

${ }^{2}$ International Child Health, Uppsala University, Uppsala

Correspondence: Hanna Sepp, Department of Domestic Sciences, Uppsala University, Dag Hammarskjölds väg 21, SE 75237 Uppsala, Sweden. E-mail: Hanna.Sepp@ihv.uu.se
}

food and nutrient intake. One system offered milk as lunch beverage, the other water. A further aim was to analyse the diet quality of low and high consumers of milk.

\section{Methods and subjects}

The study was performed in 1998. Data collection included weighed and estimated dietary recordings. The weight of all foods and drinks eaten in the pre-school was recorded on an individual basis during 5 days (Monday-Friday). At home the portion sizes were estimated (7 days, Monday-Sunday) using standard household measurements or with the help of the Meal Model, a booklet with illustrations of typical Swedish dishes and food items (23). As an inclusion criterion all parents were expected to be able to read and write Swedish. No information on ethnic background was collected. Details concerning study rationale, methods, participants' characteristics, compliance and quality control have been described previously (24).

Twelve pre-schools in a suburb of Stockholm were randomly selected. The suburb was selected, mainly because 19 of a total of 29 pre-schools were serving water as a meal beverage for lunch and the rest were serving milk and water, and partly because of the availability of a dietician responsible for menus and support for cooks and pre-school principals regarding food issues. Thus, all pre-schools received identical information and had the same opportunities to follow the same menu, but the

Table 1. Characteristics of 87 children in the different serving systems at pre-school; milk $(M)$ or water $(W)$ as a meal drink at pre-school lunch with 7 days completed food registration. Mean \pm standard deviation. T-test $p$ values.

\begin{tabular}{llcccc}
\hline & & $\begin{array}{c}M \\
\mathrm{n}=43\end{array}$ & $\begin{array}{c}W \\
\mathrm{n}=44\end{array}$ & $\mathrm{p}^{1}$ & $\begin{array}{c}\text { All } \\
\mathrm{n}=87\end{array}$ \\
\hline Age & month & $52.2 \pm 10.0$ & $62.3 \pm 5.7$ & $* * *$ & $57.3 \pm 9.5$ \\
Weight & $\mathrm{kg}$ & $17.8 \pm 2.9$ & $20.4 \pm 3.3$ & $* * *$ & $19.1 \pm 3.3$ \\
Height & $\mathrm{m}$ & $1.05 \pm 0.07$ & $1.12 \pm 0.06$ & $* * *$ & $1.08 \pm 0.07$ \\
$\begin{array}{c}\text { Predicted } \\
\text { BMR }\end{array}$ & MJ & $3.7 \pm 0.3$ & $3.9 \pm 0.3$ & $* * *$ & $3.8 \pm 0.3$ \\
& & & & & \\
\hline
\end{tabular}

$1 * * *=\mathrm{p}<0.001 ; * *=\mathrm{p}<0.01 ; *=\mathrm{p}<0.05 ; \mathrm{ns}=$ not significant 
Table 2. Children ( $n=87$ ) of different ages (months) in the different serving systems at pre-school; milk $(\mathrm{M})$ or water $(\mathrm{W})$ as a meal beverage at pre-school lunch.

\begin{tabular}{lrc}
\hline Month & M & W \\
\hline $36-41$ & 7 & 0 \\
$42-47$ & 8 & 2 \\
$48-53$ & 6 & 1 \\
$54-59$ & 11 & 5 \\
$60-65$ & 6 & 24 \\
$66-71$ & 5 & 12 \\
Total & 43 & 44 \\
\end{tabular}

principal decided whether or not they did so. The diet service used the Swedish National Food Administration (NFA) guideline (1) and Swedish Nutritional Recommendations (SNR) for menu planning (25), which recommend serving water as lunch beverage.

Two different kinds of pre-schools were selected, six offering water, and another six offering milk and water as beverage at lunch. There were no selection criteria concerning breakfast and afternoon snack. In this part of the study, 87 of the total of 131 children who completed a 7-day food record were included. Thus, 44 children were excluded for the following reasons: 9 had food records for only 5 or 6 days; 13 had food records only for pre-school; 22 consumed industrially produced gruel and were excluded because the intake of this product, which is fortified with iron, vitamin $\mathrm{C}$ and several other nutrients, might mask differences between children's nutrient intake from other foods. No children with lactose intolerance/milk allergy participated in this study. In Tables 1-4, the data are presented and grouped according to the two different serving systems, here called $M$ and $W$. In the results and discussion sections, the children are called $M$ - or $W$-children. The average intake at pre-school was calculated using the consumption of all children present at preschool. Whether a child ate a specific food was not taken into consideration. For example, if a child had breakfast 3 times and only ate cheese at two breakfasts, the total cheese consumption at breakfast was divided by 3 .

The children's weight (undressed) was measured to the nearest $0.1 \mathrm{~kg}$ using an electronic scale (Tanita, model 1618). For height measurements, to the nearest $5 \mathrm{~mm}$, a stadiometer was used. Background data on age, weight, height and predicted BMR (basal metabolic rate, MJ) are presented in Table 1. The number of children, in different age-groups participating in the different serving systems at pre-school is shown in Table 2.

\section{Data processing and statistical methods}

The food items were aggregated into 16 food groups by combining the 35 groups found in the NFA database (26), as seen

Table 3. Intake of different food groups (g) during weekdays, weekend days and the whole week for 87 children grouped in the different serving systems at pre-school: milk $(M)$ or water $(W)$ as a meal beverage at pre-school lunch. Mean \pm standard deviation. P-values from regression analyses, age used as a covariate.

\begin{tabular}{|c|c|c|c|c|c|c|c|c|c|}
\hline & \multicolumn{3}{|c|}{ Weekdays } & \multicolumn{3}{|c|}{ Weekend days } & \multicolumn{3}{|c|}{ Whole week } \\
\hline & $\begin{array}{c}M \\
\mathrm{n}=43\end{array}$ & $\begin{array}{c}W \\
\mathrm{n}=44\end{array}$ & $\mathrm{p}^{1}$ & $\begin{array}{c}M \\
\mathrm{n}=43\end{array}$ & $\begin{array}{c}W \\
\mathrm{n}=44\end{array}$ & $\mathrm{p}^{1}$ & $\begin{array}{c}M \\
\mathrm{n}=43\end{array}$ & $\begin{array}{c}W \\
\mathrm{n}=44\end{array}$ & $\mathrm{p}^{1}$ \\
\hline $\begin{array}{l}\text { Vegetables: vegetables } \\
\text { and legumes }\end{array}$ & $57 \pm 34$ & $74 \pm 44$ & ns & $58 \pm 43$ & $38 \pm 35$ & $*$ & $58 \pm 29$ & $64 \pm 36$ & ns \\
\hline Fruit: fruits and berries & $88 \pm 44$ & $107 \pm 62$ & ns & $60 \pm 63$ & $61 \pm 64$ & ns & $80 \pm 42$ & $94 \pm 47$ & ns \\
\hline Juice: fruit juices & $81 \pm 79$ & $117 \pm 76$ & ns & $43 \pm 58$ & $62 \pm 72$ & ns & $71 \pm 62$ & $101 \pm 64$ & ns \\
\hline $\begin{array}{l}\text { Potatoes: potatoes and } \\
\text { root vegetables }\end{array}$ & $72 \pm 32$ & $82 \pm 32$ & ns & $73 \pm 72$ & $87 \pm 57$ & ns & $73 \pm 32$ & $84 \pm 30$ & ns \\
\hline \multicolumn{10}{|l|}{ Dairy: } \\
\hline Milk and flavoured milk & $312 \pm 175$ & $353 \pm 150$ & ns & $231 \pm 145$ & $306 \pm 181$ & ns & $289 \pm 154$ & $339 \pm 142$ & ns \\
\hline Fermented milk & $80 \pm 69$ & $76 \pm 89$ & ns & $86 \pm 116$ & $85 \pm 107$ & ns & $82 \pm 72$ & $78 \pm 85$ & ns \\
\hline Cheese & $11 \pm 10$ & $12 \pm 9$ & ns & $10 \pm 18$ & $14 \pm 20$ & ns & $11 \pm 11$ & $13 \pm 10$ & ns \\
\hline $\begin{array}{l}\text { Meat: meat, fish, poultry, } \\
\text { eggs and seafood }\end{array}$ & $136 \pm 41$ & $137 \pm 36$ & ns & $121 \pm 55$ & $130 \pm 69$ & ns & $132 \pm 38$ & $135 \pm 36$ & ns \\
\hline $\begin{array}{l}\text { Bread: bread, porridge, } \\
\text { breakfast cereals }\end{array}$ & $56 \pm 21$ & $82 \pm 41$ & ns & $50 \pm 30$ & $70 \pm 46$ & ns & $55 \pm 18$ & $79 \pm 39$ & $*$ \\
\hline $\begin{array}{l}\text { Cereal: pasta, rice, } \\
\text { cereal, pizza, pancake }\end{array}$ & $76 \pm 36$ & $75 \pm 34$ & ns & $61 \pm 47$ & $70 \pm 53$ & ns & $72 \pm 25$ & $73 \pm 33$ & ns \\
\hline Fats: butter, margarine, oils & $24 \pm 10$ & $26 \pm 10$ & ns & $14 \pm 9$ & $15 \pm 9$ & ns & $21 \pm 9$ & $23 \pm 7$ & ns \\
\hline $\begin{array}{l}\text { Confectionery: sweets, } \\
\text { chocolate }\end{array}$ & $6 \pm 8$ & $9 \pm 12$ & ns & $34 \pm 42$ & $43 \pm 37$ & ns & $14 \pm 14$ & $18 \pm 13$ & ns \\
\hline Crisps: crisps, popcorn, nuts & $3 \pm 4$ & $4 \pm 6$ & ns & $6 \pm 17$ & $5 \pm 9$ & ns & $4 \pm 6$ & $4 \pm 5$ & ns \\
\hline Buns: buns, crackers, cakes & $12 \pm 13$ & $12 \pm 10$ & $\mathrm{~ns}$ & $34 \pm 30$ & $29 \pm 29$ & ns & $18 \pm 15$ & $17 \pm 12$ & ns \\
\hline $\begin{array}{l}\text { Soft drinks: soft drinks, } \\
\text { fruit drinks }\end{array}$ & $124 \pm 95$ & $127 \pm 79$ & $\mathrm{~ns}$ & $201 \pm 167$ & $231 \pm 167$ & ns & $146 \pm 106$ & $157 \pm 87$ & ns \\
\hline Ice cream: ice cream & $25 \pm 21$ & $25 \pm 21$ & ns & $21 \pm 29$ & $31 \pm 42$ & ns & $24 \pm 20$ & $27 \pm 20$ & ns \\
\hline $\begin{array}{l}\text { Dessert: sugar, jam, rose hip } \\
\text { soup, dessert }\end{array}$ & $70 \pm 45$ & $48 \pm 68$ & ns & $40 \pm 53$ & $38 \pm 65$ & ns & $61 \pm 37$ & $45 \pm 63$ & ns \\
\hline $\begin{array}{l}\text { Condiments: ketchup, } \\
\text { mustard, soya, vinegar }\end{array}$ & $12 \pm 32$ & $11 \pm 9$ & $\mathrm{~ns}$ & $5 \pm 7$ & $5 \pm 8$ & ns & $10 \pm 23$ & $9 \pm 8$ & ns \\
\hline
\end{tabular}

$1 * * *=\mathrm{p}<0.001 ; * *=\mathrm{p}<0.01 ; *=\mathrm{p}<0.05 ; \mathrm{ns}=$ not significant 
Table 4. Intake of energy and nutrients per meal and whole day in pre-school for children grouped in the different serving systems at pre-school: milk (M) or water $(W)$ as a meal beverage at pre-school lunch. Mean \pm standard deviation. P-values from regression analyses, age used as a covariate.

\begin{tabular}{|c|c|c|c|c|c|c|c|c|c|c|c|c|c|}
\hline & & \multicolumn{3}{|c|}{ Breakfast } & \multicolumn{3}{|c|}{ Lunch } & \multicolumn{3}{|c|}{ Snack } & \multicolumn{3}{|c|}{ Pre-school total } \\
\hline & & $\begin{array}{c}M \\
n=38\end{array}$ & $\begin{array}{c}\mathrm{W} \\
\mathrm{n}=40\end{array}$ & $\mathrm{p}^{1}$ & $\begin{array}{c}M \\
n=43\end{array}$ & $\begin{array}{c}\mathrm{W} \\
\mathrm{n}=44\end{array}$ & $\mathrm{p}^{1}$ & $\begin{array}{c}M \\
n=43\end{array}$ & $\begin{array}{c}W \\
n=44\end{array}$ & $\mathrm{p}^{1}$ & $\begin{array}{c}M \\
n=43\end{array}$ & $\begin{array}{c}W \\
n=44\end{array}$ & $\mathrm{p}^{1}$ \\
\hline Energy & MJ & $1.0 \pm 0.4$ & $1.1 \pm 0.4$ & ns & $1.4 \pm 0.6$ & $1.5 \pm 0.4$ & ns & $1.1 \pm 0.4$ & $1.3 \pm 0.4$ & ns & $3.2 \pm 1.0$ & $3.5 \pm 0.8$ & ns \\
\hline Protein & $\mathrm{g}$ & $7.0 \pm 3.1$ & $9.2 \pm 4.1$ & ns & $13.5 \pm 6.5$ & $14.2 \pm 4.7$ & ns & $7.9 \pm 2.9$ & $10.0 \pm 3.8$ & $*$ & $25.6 \pm 9.1$ & $30.2 \pm 8.9$ & ns \\
\hline Fat & $\mathrm{g}$ & $8.3 \pm 3.4$ & $9.0 \pm 3.8$ & ns & $14.4 \pm 7.2$ & $15.4 \pm 4.8$ & ns & $11.4 \pm 3.8$ & $14.1 \pm 5.8$ & ns & $30.6 \pm 10.9$ & $34.9 \pm 10.0$ & ns \\
\hline Carbohydrate & $\mathrm{g}$ & $34.5 \pm 15.7$ & $34.2 \pm 12.2$ & $\mathrm{~ns}$ & $40.2 \pm 18.0$ & $43.7 \pm 11.3$ & $3 n s$ & $34.7 \pm 13.3$ & $34.5 \pm 12.5$ & $\mathrm{~ns}$ & $95.0 \pm 33.3$ & $100.8 \pm 24.8$ & ns \\
\hline Sucrose & $\mathrm{g}$ & $6.5 \pm 5.5$ & $6.4 \pm 3.1$ & ns & $8.2 \pm 6.3$ & $6.2 \pm 2.7$ & $*$ & $10.1 \pm 6.7$ & $6.8 \pm 7.2$ & ns & $21.1 \pm 11.2$ & $16.3 \pm 8.2$ & ns \\
\hline Calcium & $\mathrm{mg}$ & $142 \pm 66$ & $209 \pm 103$ & $* *$ & $156 \pm 84$ & $114 \pm 40$ & $*$ & $160 \pm 69$ & $208 \pm 75$ & $* *$ & $403 \pm 156$ & $457 \pm 155$ & ns \\
\hline Iron & $\mathrm{mg}$ & $1.1 \pm 0.6$ & $1.0 \pm 0.4$ & ns & $2.9 \pm 2.8$ & $2.0 \pm 0.9$ & $*$ & $0.9 \pm 0.5$ & $1.0 \pm 0.7$ & ns & $4.4 \pm 3.0$ & $3.6 \pm 1.3$ & $*$ \\
\hline Zinc & $\mathrm{mg}$ & $0.9 \pm 0.4$ & $1.1 \pm 0.5$ & $\mathrm{~ns}$ & $1.8 \pm 0.9$ & $2.0 \pm 0.7$ & ns & $1.1 \pm 0.5$ & $1.4 \pm 0.5$ & $\mathrm{~ns}$ & $3.5 \pm 1.2$ & $4.1 \pm 1.3$ & ns \\
\hline Selenium & $\mu g$ & $2.7 \pm 2.0$ & $4.0 \pm 2.4$ & ns & $7.0 \pm 5.1$ & $7.1 \pm 5.2$ & ns & $2.6 \pm 1.1$ & $3.0 \pm 1.2$ & ns & $11.0 \pm 5.7$ & $12.8 \pm 5.7$ & ns \\
\hline Retinol eq & $\mu g$ & $169 \pm 167$ & $127 \pm 58$ & ns & $203 \pm 99$ & $227 \pm 115$ & ns & $137 \pm 80$ & $246 \pm 181$ & $* *$ & $444 \pm 210$ & $543 \pm 178$ & $*$ \\
\hline Riboflavin & $\mathrm{mg}$ & $0.3 \pm 0.1$ & $0.3 \pm 0.1$ & ns & $0.3 \pm 0.1$ & $0.2 \pm 0.1$ & ns & $0.2 \pm 0.1$ & $0.3 \pm 0.1$ & $*$ & $0.7 \pm 0.3$ & $0.7 \pm 0.2$ & ns \\
\hline Vitamin C & $\mathrm{mg}$ & $18.7 \pm 15.5$ & $26.7 \pm 18.0$ & $\mathrm{~ns}$ & $12.2 \pm 7.9$ & $10.4 \pm 5.7$ & $*$ & $10.8 \pm 11.1$ & $14.3 \pm 20.4$ & ns & $35.6 \pm 23.8$ & $43.9 \pm 29.0$ & ns \\
\hline Dietary fibre & $\mathrm{g}$ & $2.0 \pm 1.2$ & $1.4 \pm 0.7$ & $* *$ & $3.0 \pm 1.6$ & $3.1 \pm 1.1$ & $\mathrm{~ns}$ & $2.4 \pm 1.3$ & $2.1 \pm 0.9$ & $\mathrm{~ns}$ & $6.5 \pm 2.4$ & $6.1 \pm 1.9$ & ns \\
\hline
\end{tabular}

$1 * * *=\mathrm{p}<0.001 ; * *=\mathrm{p}<0.01 ; *=\mathrm{p}<0.05 ; \mathrm{ns}=$ not significant

Table 5. Intake of dairy products (g) per meal and total day in pre-school children grouped in the different serving systems at pre-school: milk (M) or water $(W)$ as a meal beverage at pre-school lunch. Mean \pm standard deviation. P-values from regression analyses, age used as a covariate.

\begin{tabular}{|c|c|c|c|c|c|c|c|c|c|c|c|c|}
\hline & \multicolumn{3}{|c|}{ Breakfast } & \multicolumn{3}{|c|}{ Lunch } & \multicolumn{3}{|c|}{ Snack } & \multicolumn{3}{|c|}{ Pre-school total } \\
\hline & $\begin{array}{c}M \\
n=38\end{array}$ & $\begin{array}{c}W \\
n=40\end{array}$ & $\mathrm{p}^{1}$ & $\begin{array}{c}M \\
n=43\end{array}$ & $\begin{array}{c}W \\
n=44\end{array}$ & $\mathrm{p}^{1}$ & $\begin{array}{c}M \\
n=43\end{array}$ & $\begin{array}{c}W \\
n=44\end{array}$ & $\mathrm{p}^{1}$ & $\begin{array}{c}M \\
n=43\end{array}$ & $\begin{array}{c}W \\
n=44\end{array}$ & 1 \\
\hline Milk and flavoured milk & $49 \pm 42$ & $73 \pm 51$ & $*$ & $73 \pm 55$ & 0 & $* * *$ & $75 \pm 52$ & $120 \pm 64$ & $* * *$ & $179 \pm 15$ & $169 \pm 12$ & ns \\
\hline Fermented milk & $36 \pm 44$ & $32 \pm 35$ & ns & 0 & $3 \pm 9$ & ns & $8 \pm 13$ & $1 \pm 6$ & $*$ & $31 \pm 5$ & $29 \pm 5$ & ns \\
\hline Cheese & $3 \pm 4$ & $3 \pm 4$ & ns & $1 \pm 2$ & $1 \pm 2$ & ns & $4 \pm 4$ & $4 \pm 3$ & ns & $7 \pm 1$ & $8 \pm 1$ & ns \\
\hline
\end{tabular}

$1 * * *=\mathrm{p}<0.001 ; * *=\mathrm{p}<0.01 ; *=\mathrm{p}<0.05 ; \mathrm{ns}=$ not significant

in Table 3. Food intake data were processed by the computer program Mats the Flexible (27), which included the NFA database. Recipes from the studied pre-schools and a few new products were added to the existing database. Nutrient loss was calculated according to the program for vitamin $\mathrm{C}$, with a correction factor of $-25 \%$ in unprepared dishes and $-50 \%$ in prepared warm dishes, and for riboflavin, with a correction factor of $-25 \%$ in prepared warm dishes.

The software Minitab (28) was used to calculate numerical descriptive measures and to perform regression analysis, oneway ANOVA and Tukey's pairwise comparisons.

Results are presented as means, standard deviations and pvalues, and differences with p-values $<0.05$ are considered significant. To eliminate the effect of age in the analysis of the difference between the two groups, $M$ - and $W$-children, age was used as a covariate (Tables 3-5). In order to analyse the intake of low and high consumers of milk, the children were divided into four equally sized groups based upon the consumption of milk and flavoured milk (cocoa and strawberry milk), as seen in Tables 6-8. All 4 groups were compared each to the other. However, to simplify the discussion, Groups $1+2$ are called low milk consumers and Groups 3+4 high milk consumers.

The Ethical Committee of the Faculty of Medicine, Uppsala University, approved the project protocol.

\section{Results}

Effects of serving system on the whole week's diet

Table 3 shows that there were no differences in food intake except that $M$-children had a significantly lower intake of bread and breakfast cereals over the whole week, $55 \pm 18 \mathrm{~g}$ as compared to $79 \pm 39 \mathrm{~g}$ for the $W$-children. On average the intake of milk and flavoured milk was not significantly different, $289 \pm 154 \mathrm{~g}$ for $M$ children and $339 \pm 142 \mathrm{~g}$ for $W$-children.

Though not shown in the table, in terms of whole-week diets there were no significant differences in the children's energy intake and energy percentage from the macro-nutrients attributable to the pre-school serving system. However, the $M$ children had a significantly lower intake of protein in grams. There were no significant group differences in intakes of calcium, iron, zinc, riboflavin, vitamin $\mathrm{C}$ and dietary fibre over

Table 6. Characteristics of 87 children divided into four groups on account of the amount of milk consumed per day over a seven-day period. One-way ANOVA p-values.

\begin{tabular}{|c|c|c|c|c|c|c|}
\hline & & \multicolumn{2}{|c|}{ Low milk consumers } & \multicolumn{2}{|c|}{ High milk consumers } & \multirow[b]{2}{*}{$\mathrm{p}^{1}$} \\
\hline & & $\begin{array}{c}1 \\
n=22\end{array}$ & $\begin{array}{c}2 \\
n=22\end{array}$ & $\begin{array}{c}3 \\
n=22\end{array}$ & $\begin{array}{c}4 \\
n=21\end{array}$ & \\
\hline M-children & $\mathrm{n}$ & 14 & 11 & 10 & 8 & \\
\hline W-children & $\mathrm{n}$ & 8 & 11 & 12 & 13 & \\
\hline Milk\# & $\mathrm{g}$ & $144 \pm 47^{\mathrm{a}}$ & $238 \pm 31^{\mathrm{b}}$ & $362 \pm 45^{c}$ & $523 \pm 61^{\mathrm{d}}$ & $* * *$ \\
\hline Age & month & h $54.2 \pm 10.0$ & $57.8 \pm 8.7$ & $56.8 \pm 10.1$ & $60.6 \pm 8.7$ & ns \\
\hline Weight & $\mathrm{kg}$ & $18.0 \pm 2.8^{\mathrm{a}}$ & $18.1 \pm 2.6^{\mathrm{a}}$ & $20.1 \pm 4.2^{\mathrm{b}}$ & $20.3 \pm 2.7^{\mathrm{b}}$ & $*$ \\
\hline Height & $\mathrm{m}$ & $1.05 \pm 0.07^{\mathrm{a}}$ & $1.07 \pm 0.06^{\mathrm{ab}}$ & $1.09 \pm 0.08^{\mathrm{ab}}$ & $1.12 \pm 0.06^{\mathrm{b}}$ & $* *$ \\
\hline $\begin{array}{l}\text { Predicted } \\
\text { BMR }\end{array}$ & MJ & $3.6 \pm 0.3^{\mathrm{a}}$ & $3.7 \pm 0.2^{\mathrm{ac}}$ & $3.9 \pm 0.9^{\mathrm{bc}}$ & $3.9 \pm 0.3^{b}$ & $* *$ \\
\hline
\end{tabular}

\#including flavoured milk; $1 * * *=\mathrm{p}<0.001 ; * *=\mathrm{p}<0.01 ; *=\mathrm{p}<0.05 ;$ ns $=$ not significant, Means with the same superscript letter (a,b,c or d) are not significantly different. 
Table 7. Mean and standard deviation of energy, energy percentage (E\%) and nutrient density (g/MJ) of pre-school children (n=87) divided into four groups on account of the amount of milk consumed over a seven-day period compared with the SNR recommendations. One-way ANOVA p-values.

\begin{tabular}{|c|c|c|c|c|c|c|c|}
\hline & & \multirow[b]{2}{*}{ SNR\# } & \multicolumn{2}{|c|}{ Low milk consumers } & \multicolumn{2}{|c|}{ High milk consumers } & \multirow[b]{2}{*}{$\mathrm{p}^{1}$} \\
\hline & & & $\begin{array}{c}1 \\
n=22\end{array}$ & $\begin{array}{c}2 \\
n=22\end{array}$ & $\begin{array}{c}3 \\
n=22\end{array}$ & $\begin{array}{c}4 \\
n=21\end{array}$ & \\
\hline Energy & MJ & & $5.9 \pm 1.1^{\mathrm{a}}$ & $6.0 \pm 0.7^{\mathrm{a}}$ & $6.7 \pm 1.0^{\mathrm{b}}$ & $7.5 \pm 0.8^{\mathrm{c}}$ & $* * *$ \\
\hline Protein & $\mathrm{E} \%$ & $10-15$ & $13.3 \pm 1.7^{\mathrm{a}}$ & $13.4 \pm 1.3^{\mathrm{a}}$ & $14.7 \pm 1.7^{b}$ & $14.8 \pm 1.3^{b}$ & $* * *$ \\
\hline Fat & $\mathrm{E} \%$ & $<30$ & $35.4 \pm 3.8$ & $36.5 \pm 4.0$ & $36.8 \pm 3.0$ & $35.5 \pm 4.2$ & ns \\
\hline Carbohydrate & $\mathrm{E} \%$ & $55-65$ & $53.7 \pm 4.2$ & $52.5 \pm 4.5$ & $51.1 \pm 3.9$ & $52.2 \pm 4.4$ & ns \\
\hline Sucrose & $\mathrm{E} \%$ & $<10$ & $13.0 \pm 4.3$ & $13.7 \pm 2.8$ & $10.9 \pm 3.6$ & $12.2 \pm 3.7$ & ns \\
\hline Dietary fibre & $\mathrm{g} / \mathrm{MJ}$ & 2 & $1.8 \pm 0.3^{\mathrm{a}}$ & $1.6 \pm 0.2^{b}$ & $1.7 \pm 0.3^{\mathrm{ab}}$ & $1.7 \pm 0.3^{\mathrm{ab}}$ & $*$ \\
\hline Calcium & $\mathrm{mg} / \mathrm{MJ}$ & 110 & $98.7 \pm 15.5^{\mathrm{a}}$ & $113.1 \pm 16.8^{a}$ & $136.2 \pm 26.0^{b}$ & $147.6 \pm 17.4^{\mathrm{b}}$ & $* * *$ \\
\hline Iron & $\mathrm{mg} / \mathrm{MJ}$ & 1.4 & $1.3 \pm 0.3^{\mathrm{a}}$ & $1.0 \pm 0.1^{b c}$ & $1.3 \pm 0.4^{\mathrm{a}}$ & $1.1 \pm 0.3^{\mathrm{ac}}$ & $* *$ \\
\hline Zinc & $\mathrm{mg} / \mathrm{MJ}$ & 1.1 & $1.0 \pm 0.2^{\mathrm{a}}$ & $1.0 \pm 0.1^{\mathrm{a}}$ & $1.1 \pm 0.2^{\mathrm{ac}}$ & $1.2 \pm 0.1^{b c}$ & $* *$ \\
\hline Retinol eq & $\mu \mathrm{g} / \mathrm{MJ}$ & 100 & $124.2 \pm 38.7$ & $121.7 \pm 53.2$ & $137.3 \pm 56.8$ & $122.9 \pm 42.9$ & ns \\
\hline Vitamin C & $\mathrm{mg} / \mathrm{MJ}$ & 7 & $11.7 \pm 3.1$ & $9.6 \pm 3.6$ & $10.8 \pm 3.5$ & $9.5 \pm 4.2$ & ns \\
\hline Riboflavin & $\mathrm{mg} / \mathrm{MJ}$ & 0.14 & $0.18 \pm 0.03^{a}$ & $0.18 \pm 0.02^{\mathrm{a}}$ & $0.21 \pm 0.04^{b}$ & $0.23 \pm 0.03^{b}$ & $* * *$ \\
\hline Selenium & $\mu g$ & 5 & $3.3 \pm 0.7$ & $3.3 \pm 0.8$ & $3.5 \pm 0.8$ & $3.4 \pm 0.6$ & ns \\
\hline
\end{tabular}

\# Recommended nutrient density for adults and for children $>7$ years of age

$1 * * *=\mathrm{p}<0.001 ; * *=\mathrm{p}<0.01 ; *=\mathrm{p}<0.05 ; \mathrm{ns}=$ not significant. Means with the same superscript letter $(\mathrm{a}, \mathrm{b}$ or $\mathrm{c})$ are not significantly different

the whole week, but for selenium and retinol equivalents the intakes were significantly lower among the $M$-children. There was no significant difference between the $M$ - and $W$-children regarding the intake of energy and selected nutrients at home during weekdays.

\section{Effects of serving system on the diet \\ during whole pre-school day}

Overall, there were no significant differences in the energy and nutrient intake for the whole day at the pre-school, except that the $M$-children's intakes were higher for iron and lower for retinol equivalents (Table 4). At breakfast, the $M$-children's intakes were significantly lower in calcium and higher in dietary fibre than the W-children's. At lunch, the $M$-children's intakes were significantly higher in sucrose, calcium, iron and vitamin $\mathrm{C}$ than the $W$-children's. At the afternoon snack the $M$-children's intakes were lower in protein, calcium, retinol equivalents and riboflavin than the W-children's.

For the whole pre-school day there were no significant differences in milk, fermented milk and cheese consumption (Table 5). However, there were differences between meals, especially with regard to milk and flavoured milk consumption. At breakfast the $M$-children consumed significantly smaller amounts of milk and flavoured milk $(49 \pm 42 \mathrm{~g})$ than the $W$-children $(73 \pm 51 \mathrm{~g})$. At lunch the $M$-children's average intake of milk and flavoured milk was $73 \pm 55 \mathrm{~g}$ and the $W$-children's $0 \mathrm{~g}$. The intake of milk and flavoured milk was significantly different at the afternoon snack meal, $75 \pm 52 \mathrm{~g}$ for the $M$-children and $120 \pm 64 \mathrm{~g}$ for the $W$ children. The milk and flavoured milks consumed at the preschools were low-fat $(1.5 \%)$.

\section{High and low milk consumers}

There were no significant differences in age between the four groups of milk consumers. However, there were significant differences in weight and height (Table 6). The quality of the diet for the four groups of milk consumers (independent of serving system) is shown in Tables 7 and 8 . The average energy intake increased significantly by increasing milk consumption. The low milk consumers had a significantly lower energy percentage from protein, as well as a lower density of calcium and riboflavin, than did the high milk consumers. Furthermore, the low milk consumers did not reach the recommended level for zinc, and the group with the lowest consumption of milk did not reach the level for calcium (Table 7). Regardless of milk consumption the SNR levels for iron, selenium and dietary fibre were not met.

The relative contribution of energy from the 16 food groups for the four groups of milk consumers is shown in Table 8. Group 1 had a significantly lower intake of milk and flavoured milk than Group 4 and a significantly higher intake of buns. About twice as much of the energy was covered by milk and fermented milk in Group 4 compared with Group 1. In increasing numerical order, the children in the four groups consumed the following average amounts of milk, flavoured and fermented milk: $225 \pm 72 \mathrm{~g}$, $305 \pm 69 \mathrm{~g}, 449 \pm 123 \mathrm{~g}$ and $608 \pm 101 \mathrm{~g}$. Group 1 had on average a higher, but not significantly higher, relative energy intake from fruit, juice, potatoes, meat, pasta, buns, soft drinks and ice cream and a lower intake from dairy products, bread and confectionery than did Group 4.

\section{Discussion}

\section{Serving system - M-children /W-children}

The main finding of the present study was that there were no significant differences between the children's nutrient and energy intake attributable to the serving system at the preschools. It should be noted that there was a significant difference in age between the $M$ - and $W$-children. This, however, has been taken into consideration in the statistical analyses. The average intake of milk and flavoured milk at pre-school was about 1.75 dl for both $M$ - and $W$-children. Hägg et al. (29) found that there was a significant difference in energy intake from the pre-school lunch depending on whether milk or water was served as meal beverage. They also found that milk was an important energy source when relatively unpopular dishes were served. In our study, no significant difference was found between $M$ - and $W$ children with respect to energy intake from lunch (or the whole pre-school day, breakfast or snack) at pre-school. Overall, the $M$ - 
Table 8. Relative contributions of energy (\%) from food groups in pre-school children (n=87) divided into four groups on account of the amount of milk consumed over seven days. One-way ANOVA p-values.

\begin{tabular}{|c|c|c|c|c|c|}
\hline & \multicolumn{2}{|c|}{ Low milk consumers } & \multicolumn{2}{|c|}{ High milk consumers } & \multirow[b]{2}{*}{$\mathrm{p}^{1}$} \\
\hline & $\begin{array}{c}1 \\
\mathrm{n}=22\end{array}$ & $\begin{array}{c}2 \\
n=22\end{array}$ & $\begin{array}{c}3 \\
n=22\end{array}$ & $\begin{array}{c}4 \\
n=21\end{array}$ & \\
\hline Vegetables & $1.5 \pm 1.1$ & $1.0 \pm 0.8$ & $1.7 \pm 1.0$ & $1.6 \pm 1.1$ & ns \\
\hline Fruit & $4.8 \pm 3.2$ & $3.5 \pm 2.0$ & $4.0 \pm 2.0$ & $3.3 \pm 1.6$ & ns \\
\hline Juice & $3.1 \pm 2.3$ & $1.9 \pm 1.7$ & $2.7 \pm 1.6$ & $2.5 \pm 1.6$ & ns \\
\hline Potatoes & $6.3 \pm 2.3$ & $5.6 \pm 2.6$ & $5.1 \pm 2.0$ & $4.6 \pm 2.3$ & ns \\
\hline Milk and flavoured milk & $4.3 \pm 2.0^{\mathrm{a}}$ & $8.0 \pm 10.6^{\mathrm{ac}}$ & $8.0 \pm 4.1^{\mathrm{ac}}$ & $11.7 \pm 4.9^{\mathrm{bc}}$ & $* *$ \\
\hline Fermented milk & $7.4 \pm 3.9$ & $9.7 \pm 11.6$ & $11.1 \pm 7.0$ & $10.9 \pm 5.7$ & ns \\
\hline Cheese & $2.1 \pm 1.8$ & $6.8 \pm 21.0$ & $3.4 \pm 3.3$ & $2.3 \pm 1.5$ & ns \\
\hline Meat & $18.1 \pm 4.7$ & $16.2 \pm 4.2$ & $17.1 \pm 4.2$ & $14.4 \pm 5.0$ & ns \\
\hline Bread & $12.0 \pm 4.8$ & $12.6 \pm 4.2$ & $12.8 \pm 4.4$ & $13.5 \pm 4.1$ & ns \\
\hline Cereal & $9.5 \pm 4.7$ & $8.4 \pm 3.4$ & $8.9 \pm 3.7$ & $8.6 \pm 3.6$ & ns \\
\hline Fats & $6.4 \pm 3.2$ & $7.0 \pm 2.4$ & $6.3 \pm 2.4$ & $6.8 \pm 3.2$ & $\mathrm{~ns}$ \\
\hline Confectionery & $3.2 \pm 3.3$ & $5.2 \pm 3.5$ & $3.1 \pm 2.9$ & $4.9 \pm 3.6$ & ns \\
\hline Crisps & $1.0 \pm 1.5$ & $1.3 \pm 1.2$ & $1.1 \pm 1.3$ & $1.3 \pm 2.0$ & ns \\
\hline Buns & $7.1 \pm 4.7^{\mathrm{a}}$ & $6.8 \pm 4.1^{\mathrm{a}}$ & $5.2 \pm 3.6^{\mathrm{ab}}$ & $3.6 \pm 2.6^{b}$ & $* *$ \\
\hline Soft drinks & $4.6 \pm 2.9$ & $4.6 \pm 2.3$ & $3.5 \pm 2.2$ & $3.0 \pm 1.6$ & $\mathrm{~ns}$ \\
\hline Ice cream & $3.9 \pm 3.7$ & $4.7 \pm 2.8$ & $3.0 \pm 2.4$ & $3.1 \pm 3.2$ & $\mathrm{~ns}$ \\
\hline Dessert & $5.3 \pm 3.2$ & $4.5 \pm 3.3$ & $4.6 \pm 3.4$ & $5.4 \pm 4.1$ & $\mathrm{~ns}$ \\
\hline Condiments & $0.9 \pm 0.6$ & $0.7 \pm 0.5$ & $0.8 \pm 0.6$ & $1.0 \pm 1.7$ & $\mathrm{~ns}$ \\
\hline
\end{tabular}

$1 * * *=\mathrm{p}<0.001 ; * *=\mathrm{p}<0.01 ; *=\mathrm{p}<0.05 ; \mathrm{ns}=$ not significant

Means with the same superscript letter $(\mathrm{a}, \mathrm{b}$ or $\mathrm{c}$ ) are not significantly different

children had, as could be explained by their age, a lower average intake of energy and nutrients, though only protein, selenium and retinol equivalents were significantly lower than those of the $W$ children in the seven-day period. The same pattern was shown for the intake of different foods: M-children consumed on average smaller amounts of food than did the $W$-children, although significant only in the case of bread and breakfast cereals. Looking at the total consumption of desserts and condiments, it seems as if the $M$-children had a larger average intake. This is assumed to be an error caused by the meal regime at pre-school during the study: since the $M$-children were younger on average than the $W$-children and were not used to helping themselves to sugar-rich foods, for example tomato ketchup at lunch and fruit soup at afternoon snack, they probably ate more when they could help themselves.

The $M$-children had a significantly higher intake of dietary iron for the whole day at pre-school, which was surprising and contrary to our previous assumption. However, this result was due to differences in the kinds of foods served at the pre-schools. In the case of both groups, the most important iron source was fruit juice, followed by bread, gruel and breakfast cereals. At lunch there was a significant difference in iron intake resulting from two $M$-schools serving black-pudding, which is very rich in iron $(20 \mathrm{mg}$ iron per $100 \mathrm{~g})$. At the afternoon snack there was no significant difference in iron intake. The main sources of iron for the $M$-children were fruit soup, juice and crispbread, and for the $W$-children they were sausage, bread and liver paste. More detailed information from this project concerning nutrients from different food groups will be presented in a separate paper.

Since a large number of significance tests were performed some of the significant results might be caused by erroneously rejecting a true null hypothesis (type I error) and some of the nonsignificant results might be caused by not rejecting a false null hypothesis (type II error).

\section{High and low milk consumers}

When the children were divided into four groups on account of the milk consumption, it was notable that the low milk con- sumers had a more even distribution of energy intake from different food groups than did the high milk consumers. The nutrient density for the low milk consumer was below the SNR level for zink and the lowest milk consumer was below the SNR level for calcium. Regardless of milk consumption the nutrient density means for selenium, iron and dietary fibre were below the SNR level. More information on nutrient and energy intake at pre-school and at home in relation to dietary recommendations has been presented previously (24).

The high milk consumers had a large relative contribution of energy from dairy products compared to the low milk consumers which affected the consumption of other foods. The group with the lowest consumption of milk had a more even distribution of energy intake from different food groups, such as fruit and meat, soft drinks and buns, than did the high milk consumers. This indicates that the consumption pattern of the high milk consumer was less balanced than that of the low milk consumers. Our results show that there may be a scientific reason for recommending, as health authorities do, that pre-school children's daily milk and fermented milk intake be limited to half a litre. The average calcium density for the lowest milk consumers reveals that a low intake of milk and milk products will result in a calcium density below the SNR. However, the children who consumed as little as $3 \mathrm{dl}$ of milk and fermented milk per day had a diet meeting the SNR requirements for calcium density.

The lowest milk consumers had about half as much energy in the form of milk and fermented milk as compared to Group 4, indicating that when the intake of milk and milk products is high there may be a risk that the diet will be less balanced, since the intake of other foods will be low. Furthermore, children consuming a great deal of milk and milk products might not learn to eat a variety of different foods. Research has shown that the basis for food choice is founded in childhood and that poor dietary habits learned in childhood may persist in adult life (30-32).

In Western societies there is great concern about the effects of carbonated beverages on obesity, tooth decay, osteoporosis and other health problems $(18-20,33)$. The SNR recommends limiting the intake of refined sugars to achieve a sufficient intake of 
nutrients and dietary fibre. On average the children drank more soft drinks and less milk during the weekend days than during the weekdays. There was a tendency for low milk consumers, as compared to high consumers, to receive a greater part of their energy from soft drinks and other sugar-rich foods.

\section{Conclusions}

This study showed that serving milk versus water for pre-school lunch did not affect the total milk intake at pre-school, as the children compensated for the absence of milk at lunch at other meals.

The dietary analyses showed that there might be a reason to limit pre-school children's daily milk and fermented milk intake to half a litre. If the intake of milk is low there is a risk that beverages and foods low in nutrients, such as soft drinks and sugar-rich foods, might replace the nutrient-rich milk.

\section{ACKNOWLEDGEMENTS}

The study was funded by the Faculty of Social Sciences, Uppsala University, and the Swedish Dairy Association. We would like to thank Maria Lennernäs Junberger, PhD, Lisbeth Johansson, $\mathrm{PhD}$, and Roland Pettersson, PhD, for valuable contributions.

\section{REFERENCES}

1. Wållberg L, Becker W, Enghardt H, Hagman U, Tille A: Riktlinjer för barnomsorgens måltider. Uppsala: The Swedish National Food Administration NFA. Stockholms läns landsting, Kommunförbundet; 1996. (In Swedish)

2. Expertgruppen för kost och hälsofrågor: Mjölkens och mejeriprodukternas betydelse för energi- och näringstillförseln. Vår Föda 1990;42:186-91. (In Swedish)

3. Socialstyrelen: Kost och fysisk aktivitet i barnaåldern. Socialstyrelsen redovisar Nr 33/1973: Stockholm; 1973. (In Swedish)

4. Socialstyrelsens nämnd för hälsoupplysning: Kost och aktivitet i barnaåldern. Stockholm: Liber; 1980. (In Swedish)

5. Socialstyrelsen: Kost, aktivitet och hälsa hos barn och ungdom. Stockholm Allmänna Förlaget; 1990. (In Swedish)

6. Cook JD, Dassenko SA, Whittaker P: Calcium supplementation: effect on iron absorption. Am J Clin Nutr 1991;53:106-11.

7. Hallberg L, Brune M, Erlandsson M, Sandberg AS, Rossander-Hulten L: Calcium: effect of different amounts on nonheme- and heme-iron absorption in humans. Am J Clin Nutr 1991;53:112-9.

8. Hallberg L, Rossander-Hulten L, Brune M, Gleerup A: Calcium and iron absorption: mechanism of action and nutritional importance. Eur J Clin Nutr 1992;46:317-27.

9. Hallberg L: Does calcium interfere with iron absorption? [editorial; comment]. Am J Clin Nutr 1998;68:3-4.
10. Gleerup A, Rossander-Hulthen L, Gramatkovski E, Hallberg L: Iron absorption from the whole diet: comparison of the effect of two differen distributions of daily calcium intake. Am J Clin Nutr 1995;61:97-104.

11. Hallberg L: New tools in studies on iron nutrition. Principles, applications and consequences. Scand J Nutr 2000;44:150-4.

12. Tidehag P, Sandberg AS, Hallmans G, Wing K, Turk M, Holm S, et al.: Effect of milk and fermented milk on iron absorption in ileostomy subjects. Am J Clin Nutr 1995;62(6):1234-8.

13. Reddy MB, Cook JD: Effect of calcium intake on nonheme-iron absorption from a complete diet. Am J Clin Nutr 1997;65:1820-5.

14. Minihane AM, Fairweather-Tait SJ: Effect of calcium supplementation on daily nonheme-iron absorption and long-term iron status. Am J Clin Nutr 1998;68:96-102.

15. Ames SK, Gorham BM, Abrams SA: Effects of high compared with low calcium intake on calcium absorption and incorporation of iron by red blood cells in small children. Am J Clin Nutr 1999;70:44-8.

16. Lönnerdal B: Does a high dietary intake of calcium adversely affect iron status in humans? Scand J Nutr 1999;43:82-4.

17. Hammers L: Basmätning mjölk 1999. Stockholm: LUI Marknadsinformation AB; 1999. (In Swedish)

18. Watt RG, Dykes J, Sheiham A: Preschool children's consumption of drinks: implications for dental health. Community Dent Health 2000;17:8-13.

19. Watt RG, Dykes J, Sheijham A: Drink consumption in British preschool children: relation to vitamin C, iron and calcium intakes. J Hum Nutr Diete 2000;13:13-9.

20. Harnack L, Stang J, Story M: Soft drink consumption among US children and adolescents: nutritional consequences. J Am Diet Assoc 1999;9:436-41.

21. Dennison BA, Rockwell HL, Baker SL: Excess fruit juice consumption by preschool-aged children is associated with short stature and obesity [published erratum appears in Pediatrics 1997;100:733]. Pediatrics 1997; 99:15-22.

22. Thomas LF, Keim KS, Long EM, Zaske JM: Factors related to low milk intake of 3- to 5-year-old children in child care settings. J Am Diet Assoc 1996;96:911-2.

23 The Swedish National Food Administration: The Meal Model: The Swedish National Food Administration NFA; 1997. (In Swedish)

24. Sepp H, Lennernäs M, Pettersson R, Abrahamsson L: Children's nutrient intake at pre-school and at home. Acta Paediatr 2001;90:483-91.

25. The Swedish National Food Administration (SNR): Tredje upplagan av de svenska näringsrekommendationerna. Vår Föda 1997:49:7-14. (In Swedish)

26. The Swedish National Food Administration. PC-kost 1-99. Uppsala: The Swedish National Food Administration. 1997. (In Swedish)

27. Nordin M: MATs A nutrient calculation system designed for research and education. 4.0 ed. Västerås: Rudans Lättdata; 1997. (In Swedish)

28. MINITAB: Statistical software.12.1 ed. USA: Mintab Inc; 1998.

29. Hägg A, Jacobsson T, Nordlund G, Rössner S: Effects of milk or water on lunch intake in pre-school children. Appetite 1998;31:83-92.

30. Rolls BJ, Engell D, Birch LL: Serving portion size influences 5-year-old but not 3-year-old children's food intakes. J Am Diet Assoc 2000;100:232-4.

31. Koivisto Hursti U-K: Factors influencing children's food choice. Ann Med 1999;31(Supp 1):26-32.

32. Birch LL: Development of food preferences. Annu Rev Nutr 1999;19:41-62.

33. Wyshak G: Teenaged girls, carbonated beverage consumption, and bone fractures. Arch Pediatr Adolesc Med 2000;154:610-3. 